\title{
CEsifo \\ WORKING

\section{The Impact of Declining Oil Rents on Tax Revenues: Does the Shadow Economy Matter?}

Phoebe W. Ishak, Mohammad Reza Farzanegan 


\section{Impressum:}

CESifo Working Papers

ISSN 2364-1428 (electronic version)

Publisher and distributor: Munich Society for the Promotion of Economic Research - CESifo

$\mathrm{GmbH}$

The international platform of Ludwigs-Maximilians University's Center for Economic Studies and the ifo Institute

Poschingerstr. 5, 81679 Munich, Germany

Telephone +49 (0)89 2180-2740, Telefax+49 (0)89 2180-17845, email office@cesifo.de

Editor: Clemens Fuest

https://www.cesifo.org/en/wp

An electronic version of the paper may be downloaded

- from the SSRN website: www.SSRN.com

- from the RePEc website: $\quad$ www.RePEc.org

- from the CESifo website: https://www.cesifo.org/en/wp 


\title{
The Impact of Declining Oil Rents on Tax Revenues: Does the Shadow Economy Matter?
}

\begin{abstract}
We study the association between oil rents and tax revenues, highlighting the importance of the shadow economy as a mediating factor. We present a simple theoretical model demonstrating that decreasing oil rents are likely to be positively associated with the tax revenues in a country with a moderate size of shadow economy. Declining oil rents may not lead to higher tax efforts of the state if the shadow economy is sizable. Using a sample of 124 countries from 1991 to 2015, our panel data regression analysis illustrates the moderating role of the shadow economy in the final effect of negative oil rents shocks on the tax revenues. A decline in oil rents following negative oil price shocks cease to have any significant positive impact on tax revenues in countries with shadow economy representing more than 35\% of GDP. The results are robust after controlling country and year fixed effects, other determinants of tax revenues and using a dynamic model.
\end{abstract}

JEL-Codes: Q320, Q350, H260, O170.

Keywords: shadow economy, tax revenues, oil rents, resource curse.

Phoebe W. Ishak

University of Hamburg, Faculty of Business, Economics and Social Sciences

Hamburg / Germany

phoebe.wasfy.ishak@uni-hamburg.de
Mohammad Reza Farzanegan

Philipps-University Marburg, Center for Near and Middle Eastern Studies (CNMS), Economics of the Middle East Research Group Marburg / Germany farzanegan@uni-marburg.de

This version: 17.02.2020

The authors are grateful for useful comments from Marcel Thum. The usual disclaimer applies. 


\section{Introduction}

The resource curse hypothesis implies that resource based economies, on average and in long run, have slower rate of economic growth compared to resource poor countries (see Sachs and Warner, 1995 and 2001). ${ }^{1}$ The curse of natural resources has more empirical evidence for the case of point resources such as oil (Boschini et al., 2007). There are different explanations for the oil curse (for various investigations of transmission channels of oil curse see Ishak, 2019; Farzanegan and Thum, 2018; Bjorvatn and Farzanegan, 2015; Farzanegan, 2014; Ross, 2012; Bjorvatn et al. 2012; Van der Ploeg, 2011; Tsui, 2011; Aslaksen, 2010; Frankel, 2010; Mehlum et al. 2006; Hodler, 2006; and Gylfason, 2001, among others).

One transmission channel is the negative effects of resource rents dependency on taxation capacity of the state and willingness to reform the tax system. Lower taxes in response to increasing rents may be an optimal response from an efficiency point of view as it allows governments to shift funding away from distortionary taxation. A natural question to ask would then be whether declines in oil rents are automatically followed up by proportional increases in tax revenues. In this study, we argue that the "negative" changes in oil rents could increase the willingness of the state to initiate and implement tax reforms in order to increase tax revenues, but only conditionally. In particular, we emphasize the relevance of the size of shadow economy as a key determinant of the impact of declining oil rents on tax revenues. ${ }^{2}$ Our theoretical framework demonstrates that negative shocks in oil rents promote tax efforts of the state when the size shadow economy is sufficiently moderate, whereas they have no significant positive impact on tax revenues when the shadow economy is extensive. To explain, the existence of the shadow economy offers a safe haven for business and people to conceal their economic activities from tax authorities. It follows that a rise in tax rates will have a limited effect in compensating a decline in government revenues from oil receipts in the presence of large informal economies and the respectively low tax bases.

We examine the theoretical predictions on the oil rents-tax revenues-shadow economy nexus, using panel data from 1991 to 2015 for a sample of more than 120 countries. We suggest that an expected increase in tax revenues in response to negative changes of oil rents is not happening automatically. The final effect of negative changes in oil rents on tax revenues depends on the size of the shadow economy. In countries with moderate size of the shadow economy, we may expect to observe an increase in

\footnotetext{
${ }^{1}$ Alexeev and Conrad (2009) re-examined this hypothesis and suggest that the effect of a large endowment of oil and other mineral resources on long-term economic growth of countries has been on balance positive.

${ }^{2}$ We follow the definition of shadow economy presented by Schneider (2005). His definition of the shadow economy (i.e. informal economy) covers production and transactions of "legal" goods and services that are not reported for tax purposes. This definition excludes illegal activities such as the drug trade and human trafficking. According to Schneider there are four reasons for economic agents moving from the formal to the shadow economy: (1) evading income-, value-added and other tax payments, (2) evading payments of social contribution, (3) evading implementation of special labor standards such as minimum wages, safety and environmental standards in production process, and (4) evading compliance with standard administrative processes such as completing statistical questionnaires.
} 
government tax revenues following negative oil price shocks. ${ }^{3}$ However, if the size of shadow economy is significant, then we should not experience of an increase of tax revenues. To the best of our knowledge, the moderating role of the shadow economy in the nexus between tax revenues and negative oil shocks is neglected in the literature.

Our study builds upon the "fiscal resource curse" literature. One line of this literature investigates the short-term negative effects of rents on capacity of the state to tax citizens. For examples, using the US case study, James (2015) argues that, in response to higher resource revenues, government decreases non-resource tax rates and shows that a $\$ 1$ increase in resource revenues results in a $\$ 0.25$ decrease in non-resource revenues. In another study and using a sample of resource rich economies, Crivelli and Gupta (2014) show a significant negative impact of resource rents on the taxation of goods and services. Another line of literature investigate the long-term negative effects of rents dependency on tax administration. Besley and Persson (2011, p.21) argue that a higher dependence on resource rents (or aid) which are flowing directly to the government budget may mean that market incomes are smaller. This leads to a smaller tax base which then diminishes the incentives to invest in market-supporting legal capacity. This lack of development of state administrations especially with reference to raising tax revenues is also related to rentier states hypothesis introduced initially by Mahdavy (1970) in his case study of Iran and developed in later studies such as Beblawi and Luciani (1987) (for further discussions see Besley and Persson, 2013 and 2014). ${ }^{4}$

Other scholars such as Ross $(2001,2012)$ use the fiscal channel to explain the democracy deficits in oil rich economies. The negative effect of rents on political institutions is due to response of tax revenues to positive changes in oil rents. Higher oil rents may reduce the willingness to tax citizens by the state and postponement of tax reforms. The lower fiscal dependency of the state on citizens may reduce the demand for accountability of the state to the people as well as the political participation of people. In a panel of 30 hydrocarbon producing countries Bornhorst et al. (2009) examine empirically whether there is evidence of an offset between government revenues from oil and gas related activities and revenues from other domestic sources. They show that countries that receive large revenues from the exploitation of natural resource endowments will reduce their domestic tax effort. They conclude that "there might be significant adjustment costs in moving to a higher level of domestic taxation once resources are depleted". We add to this literature by showing that the adjustment of tax efforts in response to declining resource rents is significantly constrained by the initial size of the shadow economy.

To set the scene, Section 2 presents a simple theoretical framework that demonstrates how the shadow economy may shape the impact of declining oil rents on tax revenues. In Section 3, we discuss our

\footnotetext{
${ }^{3} \mathrm{We}$ are assuming that government budget is funded by natural resource and tax revenues. One may also argue that a government, instead of closing the gap between revenues and expenditures via taxes in response to negative oil shocks, may also use debt as a buffer.

${ }^{4}$ In a theoretical and empirical investigation, Jensen (2011) also shows that "resource intensification weakens state-building by impeding the state's fiscal capacity". Fiscal capacity is defined as the state's ability to tax.
} 
empirical strategy and the data. We then proceed to present and discuss the empirical evidence and some robustness analyses in Section 4. We conclude the article in Section 5.

\section{Theoretical Framework}

We develop a simple model of government choice between using oil rents and taxation for financing public goods. The difference between both sources lies in the fact that taxation is distortive and creates welfare losses (Bornhorts et al., 2009). Hence, the government will depend on the oil rents as a first option. If oil rents suddenly declined, the government will resort to taxing firms. In this model, we assume that a rational citizen will understand that using oil rents for financing public goods is also considered a tax. If the money were not used for this purpose, he/she could receive a transfer instead. As such, the government's total received tax revenues encompasses both oil rents and imposed corporate taxes.

Suppose that the individual's utility function takes the following form $U(Y, T)$, where $Y$ denotes private net income (i.e. consumption) and $T$ is a government transfer or the size of the received public good. The government receives an exogenous amount of oil rents of $p R$, where $p$ is the international oil price and $R$ is amount of oil extraction. The government can tax firms, with each firm $n$ is charged a tax rate of $t$. However, the government can only tax firms operating in the official economy. The share of the firms in the shadow economy $f(t, x)$ is a function of tax rate $t$ and the willingness of the firm to operate in the shadow economy even in the absence of taxation $x$ (i.e. subsistence level of the shadow economy). We assume that share of firms in the shadow economy is increasing in both $t$ and $x$, thus $\frac{d f}{d t}>0$ and $\frac{d f}{d x}>0$. It then follows that the size of the public $\operatorname{good}(T)$ is

$$
T=p R+[1-f(t, x)] t n
$$

and net income $(Y)$ is

$$
Y=[(1-f(t, x))(1-t)+f(t, x)] n=n[1-t(1-f(t, x)]
$$

Assuming Cobb-Douglas utility function $U(Y, T)=Y^{a} T^{1-a}$ and a uniform distribution of firms in the shadow economy $f(t, x)=\frac{t}{(1-x)}$, then our utility function becomes

$$
U=\left[n\left[1-t\left(1-\frac{t}{(1-x)}\right)\right]^{a}\left[p R+\left[1-\frac{t}{(1-x)}\right] t n\right]^{1-a}\right.
$$

With $t$ and $x \in[0,1]$. Using the first order conditions $d U / d t$ and assuming an internal solution, we can get

$$
\frac{d U}{d Y}-\frac{d U}{d T}=0
$$


This means that the marginal utility from private consumption and marginal utility of public good should be equal. ${ }^{5}$ Under this condition, we see

$$
a\left[p R+\left[1-\frac{t}{(1-x)}\right] t n\right]-[1-a]\left[n\left[1-t\left(1-\frac{t}{(1-x)}\right)\right]=0\right.
$$

Using implicit differentiation,

$$
\frac{d t}{d p}=-a p\left[\frac{1-x}{n(1-x-2 t)}\right]
$$

From the second order condition,

$$
\frac{d^{2} t}{d p^{2}}=-a\left[\frac{1-x}{n(1-x-2 t)}\right]<0
$$

if $1-x-2 t>0$, which makes

$$
d t / d p<0
$$

To see how the change in $x$ affects $d t / d p$, we get

$$
d / x\left(\frac{d t}{d p}\right)=\frac{-a p 2 t}{n(1-x-2 t)^{2}} \quad<0
$$

We observe that the impact of a change in $p$ depends on $x$, that is subsistence level of the shadow economy. We therefore can make the following two propositions:

Observation 1: an exogenous decline in $p$ increase tax rate $t$

Observation 2: an exogenous decline in $p$ has a smaller impact on $t$, the higher the size of $x$ Observation 1 is based on equation (8), while observation 2 is based on equation (9), the latter is due to the fact that the share of firms willing to operate in the official economy becomes smaller with the increase in $x .^{6}$

\section{Data and Empirical Specification}

Our main prediction from the theoretical model is that the shadow economy matters for whether declining oil rents following negative oil price shocks are promoting tax efforts of government. In particular, such negative shocks to oil rents are more likely to have a positive effect on tax revenues if the shadow economy is moderate, whereas declining oil rents in a situation with a sizable shadow economy may not lead to higher tax efforts and revenues.

\footnotetext{
${ }^{5}$ We also checked for internal solutions assuming $\mathrm{U}(\mathrm{Y}, 0)$ or $\mathrm{U}(0, \mathrm{~T})$, but both solutions were rejected for having contradictory signs.

${ }^{6}$ An alternative to equation (9) would be that with high $x$, the term $1-x$ becomes very small, such that the $\lim _{x \rightarrow 1} 1-x \rightarrow 0$. It then follows that $\lim _{x \rightarrow 1} \frac{d t}{d p} \rightarrow 0$
} 


\subsection{Data}

We use a panel dataset covering 124 countries over the period 1991-2015. Our main specification uses 3 -year averages of our measures of tax revenues, oil price shocks, shadow economy and per capita income. This allows us to overcome instances of missing data for some countries, especially tax revenues, and have a more balanced dataset. Nevertheless, our results do not depend on the use of 3year averages. ${ }^{7}$ Appendix A presents the list of countries included in the sample. To measure oil price shocks $d p$, we use the 3-year change in $(\log )$ international oil prices as a proxy. Hence, our measure for oil price shock for country $i$ at time $t$ takes the following form (Eq. 10):

$$
\text { OilPriceShock }_{i t}=\delta_{i}\left(\ln \text { OilPrice }_{t}-\ln \text { OilPrice }_{t-3}\right)
$$

where $\delta_{i}$ represents the whole-period average of country's $i$ share of oil exports to GDP multiplied by the 3-year change of (log) international real oil prices (ln OilPrice $_{t}$ ). The construction of the measure captures that oil price shocks will have a greater impact in countries with a higher oil dependency. ${ }^{8}$ It also allows us to circumvent problems associated with using conventional measures of oil wealth such as export or production levels (typically normalized by GDP or population) which could be spuriously correlated with our outcome of interest. The oil exports data are from the United Nations' Comtrade dataset reported according to the SITC1 system (UN Comtrade, 2018). Data on international real oil prices is taken from British Petroleum database (BP, 2018). To differentiate negative oil price shocks from positive shocks, we construct a variable that takes the value of three-year ln-change of oil prices, if this value is strictly negative and zero otherwise. ${ }^{9}$ Negative oil price shocks are first calculated per year for each country and then collapsed to the three-year average.

Taxes rate $t$ is measured by the ratio of tax revenue to GDP taken from the World Bank's World Development Indicators (WDI, 2018). Our proxy for the subsistence level of shadow economy $x$ is the share of shadow economy to GDP taken from Medina and Schneider (2018). The estimates for the size of the shadow economy are based on the Multiple Indicators Multiple Causes (MIMIC) model. This empirical approach first treats the shadow economy as an unobserved (latent) variable, identifying multiple causes and multiple indicators for estimating its size. ${ }^{10}$ Second, it uses structural equations model to estimate the relationships between the unobserved variable and the observed indicators. A key advantage of this dataset is that it uses a light intensity approach instead of GDP as an indicator variable, and hence, it captures a wider range of economic activities that are not reported by official GDP figures. A second advantage of this dataset is the inclusion of a longer time span and wider coverage of countries.

\footnotetext{
${ }^{7}$ Our results remain robust when using annual data or 5-year averages.

8 See Bazzi and Blattman (2014), Brückner and Ciconne (2010), and Brückner et al. (2012) for similar methodology.

${ }^{9}$ See Farzanegan and Markwardt (2009) for similar methodology.

${ }^{10}$ See Medina and Schneider (2018) for more technical information about the construction of the shadow economy estimates.
} 
Moreover, we control for real GDP per capita from World Development Indicators (WDI, 2018). Table 1 provides the summary statistics for our main variables of interest.

Table 1. Summary Statistics

\begin{tabular}{lccccc}
\hline \hline Variable & N & Mean & SD & Min & Max \\
\hline Tax revenue (\% of GDP) (log) & 799 & 2.69 & 0.65 & -1.34 & 4.06 \\
Negative oil price Shock (3-year growth) & 799 & -0.01 & 0.02 & -0.17 & 0.00 \\
Shadow economy (\% of GDP) & 799 & 28.81 & 13.38 & 6.52 & 70.93 \\
GDP per capita (log) & 799 & 8.86 & 1.45 & 5.15 & 11.58 \\
\hline
\end{tabular}

To get a first snapshot of the data, Figures 1 and 2 plot changes in (log) tax revenue to GDP against negative oil price shocks in high- and low-shadow economy countries. We define countries to be a high (low)-shadow economy countries, if the size of the shadow economy is greater (lower) than the median. Figure 1 shows hardly any relationship between $(\log )$ changes in tax revenue to GDP and negative price shocks in high-shadow economy countries. The slope of coefficient is equal to 0.69 and is statistically insignificant. Fig. 2 shows, in contrast, a positive and statistically significant relationship in low-shadow economy countries. The slope of coefficient is equal to 1.20 and is statistically significant at $1 \%$ significance level.

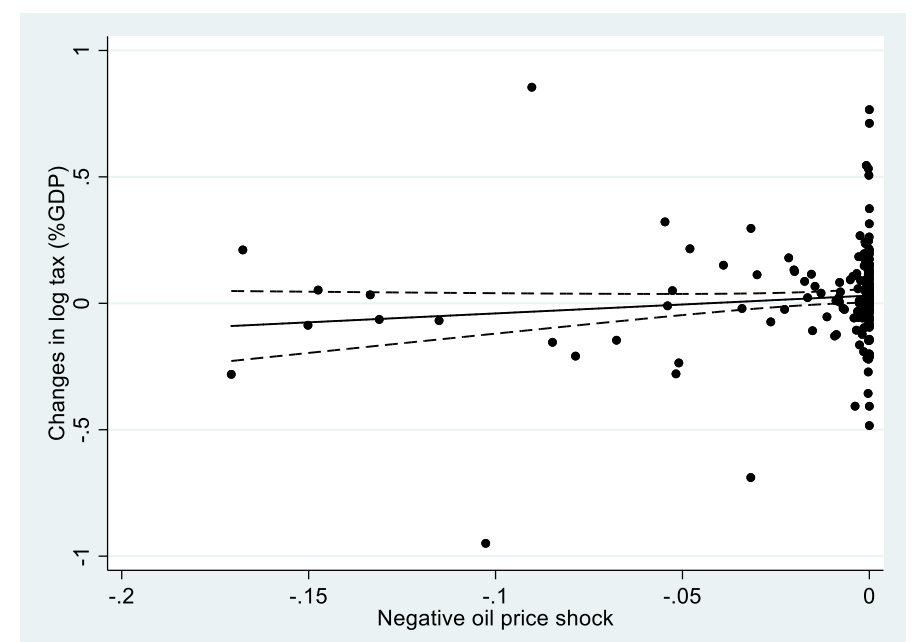

Fig. 1. Changes in (log) tax revenue to GDP and negative oil price shocks in high-shadow economy countries. A country is considered a high-shadow economy country, if the size of the shadow economy is greater than the median. The dashed lines are the $90 \%$ confidence interval. 


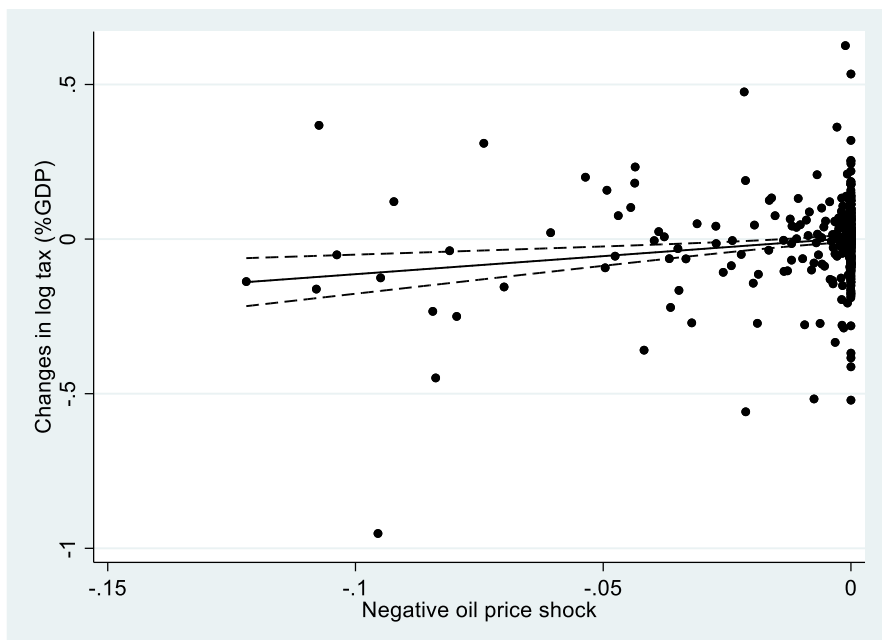

Fig. 2. Changes in $(\log )$ tax revenue to GDP and negative oil price shocks in low-shadow economy countries. A country is considered a low-shadow economy country, if the size of the shadow economy is lower than the median. The dashed lines are the $90 \%$ confidence interval.

\subsection{Empirical Specification}

Recall that our theoretical model predicts that the effect of negative oil price shock on tax revenues depends on the initial size of the shadow economy. Specifically, a negative exogenous decline in oil rents shall increase tax revenues, but the effect is lower the higher the size of shadow economy. To test this hypothesis, we estimate the following model:

$$
\begin{aligned}
& \operatorname{lnTaxRev}_{i t}=\alpha_{i}+\gamma_{t}+\beta_{1} \text { NegPriceShock }_{i t}+\beta_{2} \text { SE }_{i t-3}+\beta_{3} \text { NegPriceShock }_{i t} \times \\
& S E_{i t-3}+\beta_{4} \operatorname{lnGDP}_{i t}+\varepsilon_{i t}
\end{aligned}
$$

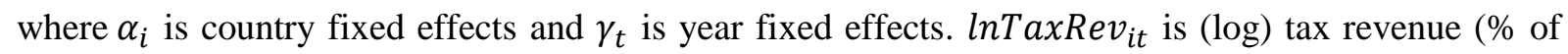
GDP) in country $i$ and year $t$ and is our proxy for tax rate $t$; NegPriceShock is our proxy for a negative oil rents shock $d p$; $\ln G D P_{i t}$ is $(\log )$ GDP per capita and $\varepsilon_{i t}$ is a disturbance term. $S E_{i t-3}$ is the initial size of the shadow economy (\% of GDP) lagged one period to address reverse feedback concerns, since it is less unlikely that tax revenues and price shocks at year $t$ will affect the size of shadow economy at year $t-3 .^{11}$ This suggests that a lagged level of the shadow economy can be treated as a predetermined variable, whose lagged values are uncorrelated with the current error term. In this specification, $\beta_{1}$ captures the linear effect of negative oil price shocks on tax revenues in countries more dependent on oil, and $\beta_{3}$ measures the effect of negative oil price shocks on tax revenue conditional upon the initial size of the shadow economy. According to our theoretical prediction, the sign of the linear effect should

\footnotetext{
${ }^{11}$ Results remain robust, when we use the second lag of shadow economy, despite the drop in sample size. See Ishak and Fritsche (2019) for their findings on the insignificant response of lagged shadow economy to oil price shocks. We include shadow economy in level rather than in logs to address multi-collinearity concerns. (i.e. the variance inflation factor (VIF) is, on average, 17.37, when using (log) shadow economy, whereas it drops to only 6.75 when using the shadow economy in levels. Conventionally, it is recommended that VIF should not exceed 10 , otherwise the model would suffer from multi-collinearity.)
} 
be positive $\left(\beta_{1}>0\right)$ and the sign of the interaction effect should be negative $\left(\beta_{3}<0\right)$. Hence, the higher initial size of the shadow economy, the lower effect of oil price shocks on tax revenues.

The inclusion of (log) GDP per capita controls for the effect of oil price shocks on GDP (i.e. the denominator in $\frac{\text { Tax Revenue }}{G D P}$ ). This ensures that we capture the effect of negative oil prices on the size of tax revenues (i.e. nominator) and not on GDP. ${ }^{12}$ In this approach, the time variation stems from movements in international oil prices, while allowing the effect to change based on the degree of oil dependency. The included fixed effects control for all time-invariant country characteristics and global trends. We cluster the standard errors at the country level.

\section{Empirical Results}

\subsection{Main Results}

Table 2 contains our mains empirical results. Column 1 looks at the average impact of negative oil price shocks on (log) tax revenues (\% of GDP) without controlling for the initial size of the shadow economy. It shows that negative oil price shocks have a positive, but statistically insignificant impact on tax revenues. In columns 2 and 3, we split our sample into high-and low-shadow economy countries, if the lagged size of the shadow economy (\% of GDP) is greater or lower than the median, respectively. Column 2 shows a positive, but statistically insignificant effect of negative oil price shocks on taxes in high-shadow economy countries. In contrast, the effect is positive and statistically significant in lowshadow economy countries as reported in column 3 .

In column 4, instead of sample split, we add the lagged level of the shadow economy both by itself and interacted with negative oil price shocks. The coefficient of negative oil price shocks is positive and statistically significant at 5\% significance level, while the coefficient of the interaction term is negative and statistically significant at $10 \%$ significance level. This suggest that negative oil price shocks lead to an increase in the tax revenues share of GDP, but the positive effect reduces at higher initial levels of GDP.

In columns 5 and 6, we add the lagged dependent variable as an additional explanatory variable and estimate a dynamic panel model. Column 5 shows the result using OLS estimation, while column 6 reports the results using system-GMM estimation. ${ }^{13}$ In both columns, the coefficients of our main variables of interest keep their signs and statistical significance.

In column 7, we estimate the model in first differences by employing the one-period change in (log) tax revenues as our dependent variable. This approach has the advantage of controlling for all countryspecific linear trends in tax revenues, when combined with country fixed effects. We continue to find a

\footnotetext{
${ }^{12} \mathrm{We}$ acknowledge that a potential concern regarding our measure for shadow economy (SE) is its estimated size is based on the MIMIC approach, which treats tax revenue as a percentage of GDP as one of the drivers for the shadow economy. It should be noted that even though our measure for SE could be endogenous, the interaction term between negative oil price shocks (i.e. exogenous variable) and SE remain consistent (see Bun and Harrison, 2019).

${ }^{13}$ We also estimated first-differences GMM model. The results do not change.
} 
positive impact of negative oil price shocks on tax revues and the impact is higher the lower the initial size of the shadow economy.

Table 2. Negative oil price shocks, taxation and shadow economy

\begin{tabular}{|c|c|c|c|c|c|c|c|}
\hline Model & $(1)$ & $(2)$ & (3) & (4) & $(5)$ & $(6)$ & $(7)$ \\
\hline & $\ln T a x$ & $\ln$ Tax & $\ln T a x$ & $\ln$ Tax & $\ln$ Tax & $\ln T a x$ & $\Delta \ln T a x$ \\
\hline & OLS & OLS & OLS & OLS & OLS & SYS-GMM & OLS \\
\hline & & High SE & Low SE & Baseline & Lagged Taxes & Lagged Taxes & \\
\hline Negative price shock, $t$ & $\begin{array}{c}2.227 \\
(1.386)\end{array}$ & $\begin{array}{c}0.697 \\
(1.348)\end{array}$ & $\begin{array}{l}4.053 * * \\
(1.571)\end{array}$ & $\begin{array}{l}6.411 * * \\
(2.529)\end{array}$ & $\begin{array}{l}5.180^{* * *} \\
(1.019)\end{array}$ & $\begin{array}{l}7.601^{* *} \\
(3.578)\end{array}$ & $\begin{array}{l}2.706^{* *} \\
(1.072)\end{array}$ \\
\hline Shadow economy, $t-1$ & & & & $\begin{array}{c}0.002 \\
(0.005)\end{array}$ & $\begin{array}{l}-0.001 \\
(0.002)\end{array}$ & $\begin{array}{c}0.001 \\
(0.001)\end{array}$ & $\begin{array}{c}-0.004 \\
(0.003)\end{array}$ \\
\hline $\begin{array}{l}\text { Negative price shock, } t \times \\
\text { Shadow economy, } t-1\end{array}$ & & & & $\begin{array}{l}-0.125^{*} \\
(0.068)\end{array}$ & $\begin{array}{c}-0.138 * * * \\
(0.025)\end{array}$ & $\begin{array}{l}-0.140^{*} \\
(0.073)\end{array}$ & $\begin{array}{l}-0.074 * \\
(0.043)\end{array}$ \\
\hline GDP per capita $(\log ), t$ & $\begin{array}{c}0.306 * * \\
(0.126)\end{array}$ & $\begin{array}{c}0.156 \\
(0.144)\end{array}$ & $\begin{array}{c}0.324 \\
(0.200)\end{array}$ & $\begin{array}{c}0.326 * * \\
(0.139)\end{array}$ & $\begin{array}{l}0.151 * * \\
(0.069)\end{array}$ & $\begin{array}{l}0.025^{*} \\
(0.013)\end{array}$ & \\
\hline $\operatorname{lnTax}, t-1$ & & & & & $\begin{array}{c}0.629 * * * \\
(0.064)\end{array}$ & $\begin{array}{c}0.785^{* * * *} \\
(0.088)\end{array}$ & \\
\hline$\Delta$ GDP per capita $(\log ), \mathrm{t}$ & & & & & & & $\begin{array}{c}0.325^{* * *} \\
(0.118) \\
\end{array}$ \\
\hline Number of observations & 799 & 276 & 523 & 799 & 726 & 726 & 725 \\
\hline Number of countries & 124 & 63 & 96 & 124 & 119 & 119 & 119 \\
\hline R-squared & 0.083 & 0.123 & 0.119 & 0.095 & 0.500 & & 0.086 \\
\hline $\mathrm{AR}(1)$ & & & & & & 0.01 & \\
\hline AR (2) & & & & & & 0.10 & \\
\hline Hansen test, $p$-value & & & & & & 0.41 & \\
\hline Country FE & Yes & Yes & Yes & Yes & Yes & Yes & Yes \\
\hline Year FE & Yes & Yes & Yes & Yes & Yes & Yes & Yes \\
\hline
\end{tabular}

Our main results (based on column 4) are illustrated in Figure 3, which plots the estimated effect of negative oil price shocks on tax revenues conditional upon the initial size of the shadow economy, along with the $90 \%$ confidence bands. The plot shows that the increase in tax revenues following negative oil price shocks is lower, the higher the initial size of the shadow economy. In a low-shadow economy country (shadow economy around 7\% of GDP), the effect of 1 percentage point weighed-decline in international oil price implies an increase in tax revenues by 5.5 percentage points. In a mid-shadow economy country (shadow economy around 32\% of GDP), the effect of 1 percentage point weigheddecline in international oil price implies an increase in tax revenues by 2.4 percentage points. Negative oil price shocks cease to have any significant impact on tax revenues in high-shadow economy countries, with shadow economy representing more than $35 \%$ of GDP. ${ }^{14}$ To put things differently, let us consider Iran and Republic of Congo as examples oil dependent countries, with shadow representing on average 19 percent and 50 percent of GDP, respectively. A 1-percentage point decline in weighed-international oil prices increases tax revenues in Iran by 4-percentage point, but will have no significant impact on tax revenues in the republic of Congo.

\footnotetext{
${ }^{14}$ In Appendix A, we present the list of countries whose shadow economies represent more than $35 \%$ of GDP.
} 


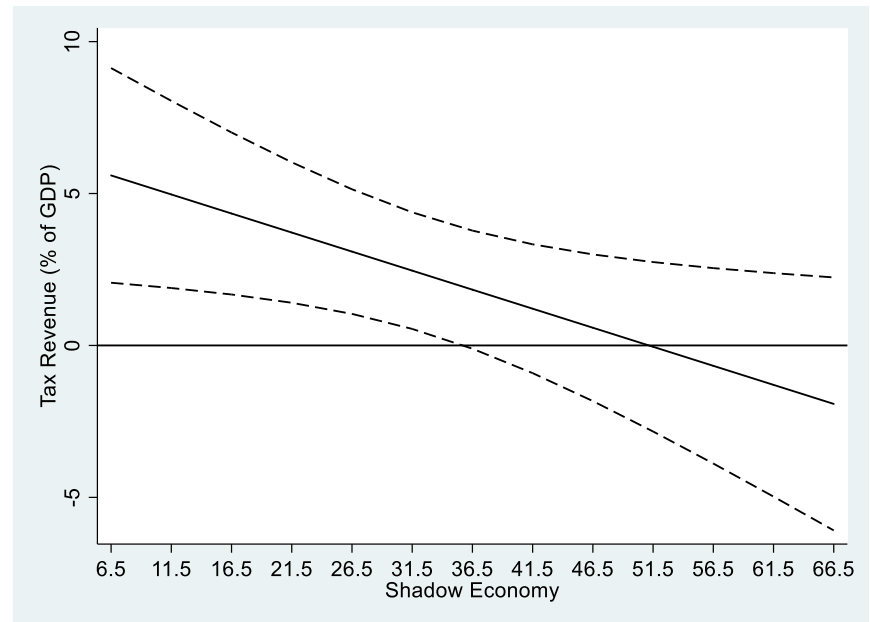

Fig. 3. Marginal effects of negative oil prices shocks on tax revenue (\% of GDP) at different levels of shadow economy ( $\%$ of GDP). The dashed lines represent the $90 \%$ confidence intervals.

\subsection{Robustness Checks}

In Table 3, we add additional control variables to our baseline model. In column 1, we add the share of agriculture value added to GDP to control for the fact that economy-dominated agriculture sectors may be difficult in the presence of large number of subsistence farmers (Gupta, 2007). In column 2, we add the share of imports and exports to GDP as a proxy for degree of openness. Trade liberalization could either negatively affect government revenues by reducing tariffs receipts, or increase revenue mobilization through eliminations of exemptions and improvement in customs procedure (Keen and Simone, 2004). In column 3, we control for the share of foreign aid receipts to GNI. Aid could affect the domestic revenue mobilization efforts depending on the type of aid received and its domestic use (i.e. to finance investments or current consumption). Gupta et al. (2004) find that concessional loans increase domestically generated taxation, while grants exerts the opposite impact. In columns 4-7, we control for different measures of the quality of institutions and state effectiveness (Besley and Persson, 2014). Corruption could reduce tax revenues by facilitating tax evasion. Low contestability of power, measured by Polity2 score ${ }^{15}$ and executive constraints from Polity IV database (Marshall et al., 2018), reduces the incentives of the ruling elites to impose progressive tax rates and deliver efficient public services. Political instability, measured by durable variable from Polity IV, lowers the ability of the government to impose efficient tax systems and to monitor compliance. All factors result in low tax base and lower tax compliance rates. Finally, in column 8, we control for social-cultural norms affecting tax morals. Ethnically fractionalized states have a weaker sense of national identity, which intern weakens their moral obligations towards tax payments (Besley and Persson, 2014). Throughout all columns, our main results remain robust in sign and statistical significance.

\footnotetext{
${ }^{15}$ Following Brückner and Ciccone (2010), we adjust Polity2 so that periods of interregnum, coded as 0 , and transitionary periods are treated as missing.
} 
Table 3. Adding additional control variables

\begin{tabular}{|c|c|c|c|c|c|c|c|c|}
\hline Model & (1) & (2) & (3) & (4) & (5) & (6) & (7) & (8) \\
\hline & $\ln T a x$ & $\ln T a x$ & $\ln T a x$ & $\ln T a x$ & $\ln T a x$ & $\ln T a x$ & $\ln T a x$ & $\ln T a x$ \\
\hline & OLS & OLS & OLS & OLS & OLS & OLS & OLS & OLS \\
\hline Negative price shock, $t$ & $\begin{array}{l}7.096 * * * \\
(2.446)\end{array}$ & $\begin{array}{l}6.325 * * \\
(2.665)\end{array}$ & $\begin{array}{l}9.759 * * * \\
(2.099)\end{array}$ & $\begin{array}{l}7.442 * * * \\
(2.389)\end{array}$ & $\begin{array}{l}6.912 * * * \\
(2.552)\end{array}$ & $\begin{array}{l}7.111 * * * \\
(2.601)\end{array}$ & $\begin{array}{c}7.023 * * * \\
(2.594)\end{array}$ & $\begin{array}{l}6.447 * * \\
(2.510)\end{array}$ \\
\hline Shadow economy, $t-1$ & $\begin{array}{c}0.003 \\
(0.005)\end{array}$ & $\begin{array}{c}0.000 \\
(0.005)\end{array}$ & $\begin{array}{l}-0.001 \\
(0.004)\end{array}$ & $\begin{array}{l}-0.001 \\
(0.005)\end{array}$ & $\begin{array}{c}0.002 \\
(0.005)\end{array}$ & $\begin{array}{c}0.002 \\
(0.005)\end{array}$ & $\begin{array}{c}0.002 \\
(0.005)\end{array}$ & $\begin{array}{c}0.002 \\
(0.005)\end{array}$ \\
\hline $\begin{array}{l}\text { Negative price shock, } t \times \\
\text { Shadow economy, } t-1\end{array}$ & $\begin{array}{c}-0.139 * * \\
(0.069)\end{array}$ & $\begin{array}{l}-0.125^{*} \\
(0.072)\end{array}$ & $\begin{array}{c}-0.211^{* * *} \\
(0.048)\end{array}$ & $\begin{array}{c}-0.174 * * * \\
(0.057)\end{array}$ & $\begin{array}{l}-0.151^{*} \\
(0.077)\end{array}$ & $\begin{array}{l}-0.157^{*} \\
(0.080)\end{array}$ & $\begin{array}{l}-0.152 * \\
(0.078)\end{array}$ & $\begin{array}{l}-0.126^{*} \\
(0.067)\end{array}$ \\
\hline GDP per capita $(\log ), t$ & $\begin{array}{c}0.469 * * * \\
(0.156)\end{array}$ & $\begin{array}{l}0.305^{* *} \\
(0.152)\end{array}$ & $\begin{array}{c}0.361^{* *} \\
(0.157)\end{array}$ & $\begin{array}{c}0.295 * * \\
(0.147)\end{array}$ & $\begin{array}{c}0.339 * * \\
(0.144)\end{array}$ & $\begin{array}{l}0.326^{* *} \\
(0.143)\end{array}$ & $\begin{array}{l}0.326 * * \\
(0.143)\end{array}$ & $\begin{array}{c}0.327^{* *} \\
(0.138)\end{array}$ \\
\hline Additional Controls & $\begin{array}{l}\text { Agriculture } \\
\text { value added } \\
(\% \text { GDP) (log) }\end{array}$ & $\begin{array}{c}\text { Trade } \\
(\% \text { GDP })\end{array}$ & $\begin{array}{c}\text { Aid } \\
(\% \text { GNI }) \\
(\log )\end{array}$ & $\begin{array}{l}\text { Corruption } \\
\quad(\log )\end{array}$ & Polity2 & $\begin{array}{l}\text { Executive } \\
\text { constraints }\end{array}$ & $\begin{array}{l}\text { Political } \\
\text { instability }\end{array}$ & Ethnicity \\
\hline & $\begin{array}{c}0.125 \\
(0.085) \\
\end{array}$ & $\begin{array}{l}0.0001 \\
(0.001) \\
\end{array}$ & $\begin{array}{c}0.050^{* *} \\
(0.021) \\
\end{array}$ & $\begin{array}{l}-0.029 \\
(0.060) \\
\end{array}$ & $\begin{array}{c}0.005 \\
(0.006) \\
\end{array}$ & $\begin{array}{c}0.002 * * * \\
(0.000) \\
\end{array}$ & $\begin{array}{c}0.002 \\
(0.002) \\
\end{array}$ & $\begin{array}{c}0.004 \\
(0.020) \\
\end{array}$ \\
\hline Number of observations & 753 & 759 & 467 & 720 & 754 & 766 & 766 & 799 \\
\hline Number of countries & 123 & 122 & 89 & 111 & 119 & 120 & 120 & 124 \\
\hline R-squared & 0.153 & 0.086 & 0.193 & 0.099 & 0.103 & 0.108 & 0.104 & 0.095 \\
\hline Country FE & Yes & Yes & Yes & Yes & Yes & Yes & Yes & Yes \\
\hline Year FE & Yes & Yes & Yes & Yes & Yes & Yes & Yes & Yes \\
\hline
\end{tabular}

Table 4 presents a number of robustness checks using alternative samples. To the extent that international oil prices are exogenous to specific countries demand or supply shocks, we should get an unbiased estimates for $\beta_{1}$ and $\beta_{3}$ in our baseline specification. Nevertheless, we cannot rule out the possibility of price manipulations triggered by major oil producers. To address that, in columns 1-3 we exclude major oil producers -whose production exceeds $1 \%$ or $3 \%$ of world production- and OPEC countries. ${ }^{16}$ In columns 4 and 5, we check whether our results driven by high-SE countries or by low oil exporters. In column 4 , we exclude the top 1 percent countries in the size of the shadow economy as a percentage of GDP. ${ }^{17}$ In column 5, we drop low oil exporters, whose average share of oil exports to GDP is lower than the median. In all instances, our coefficients of interest keep their sign and statistical significance. In columns 6 and 7, we weigh our measure for negative oil price changes (i.e. $\delta_{i}$ ) once with country's whole-period average of oil production ( $\%$ of GDP) and another with the country's whole-period average of oil rents (\% of GDP). In both cases, the coefficient of negative oil price shocks remain positive and statistically significant. The conditioning term loses its statistical significant but keeps its positive sign. Nevertheless, the estimated marginal effects of negative oil prices at different levels of shadow economy remain the same as the baseline specification (see Appendix B).

\footnotetext{
${ }^{16}$ Data on world oil production is calculated using Ross and Mahdavy (2015) oil and gas database. We also excluded the top 10 oil producers based on CIA world Factbook and results remain unchanged.

${ }^{17}$ Exclusion of observations corresponding to the highest $1 \%$ and $5 \%$ of shadow economy values do not change our results.
} 
Table 4. Alternative samples and weights

\begin{tabular}{|c|c|c|c|c|c|c|c|}
\hline Model & (1) & $(2)$ & (3) & $(4)$ & (5) & (6) & $(7)$ \\
\hline & $\ln$ Tax & $\ln$ Tax & $\ln$ Tax & $\ln$ Tax & $\ln$ Tax & $\ln$ Tax & $\ln T a x$ \\
\hline & OLS & OLS & OLS & OLS & OLS & OLS & OLS \\
\hline Negative price shock, $t$ & $\begin{array}{c}8.603 * * * \\
(2.492)\end{array}$ & $\begin{array}{l}8.831 * * * \\
(2.325)\end{array}$ & $\begin{array}{l}7.893 * * * \\
(2.279)\end{array}$ & $\begin{array}{l}6.272 * * \\
(2.566)\end{array}$ & $\begin{array}{l}6.417 * * \\
(2.514)\end{array}$ & $\begin{array}{l}3.799 * \\
(1.939)\end{array}$ & $\begin{array}{l}4.844^{*} \\
(2.798)\end{array}$ \\
\hline Shadow economy, $t-1$ & $\begin{array}{c}0.004 \\
(0.005)\end{array}$ & $\begin{array}{c}0.002 \\
(0.005)\end{array}$ & $\begin{array}{c}0.002 \\
(0.005)\end{array}$ & $\begin{array}{l}-0.001 \\
(0.004)\end{array}$ & $\begin{array}{c}0.001 \\
(0.008)\end{array}$ & $\begin{array}{c}0.004 \\
(0.007)\end{array}$ & $\begin{array}{c}0.005 \\
(0.007)\end{array}$ \\
\hline $\begin{array}{l}\text { Negative price shock, } t \times \\
\text { Shadow economy, } t-1\end{array}$ & $\begin{array}{c}-0.151 * * \\
(0.072)\end{array}$ & $\begin{array}{l}-0.133^{*} \\
(0.075)\end{array}$ & $\begin{array}{c}-0.156^{* *} \\
(0.063)\end{array}$ & $\begin{array}{l}-0.121^{*} \\
(0.068)\end{array}$ & $\begin{array}{l}-0.124 * \\
(0.067)\end{array}$ & $\begin{array}{l}-0.064 \\
(0.054)\end{array}$ & $\begin{array}{l}-0.076 \\
(0.090)\end{array}$ \\
\hline GDP per capita $(\log ), t$ & $\begin{array}{l}0.351 * * \\
(0.140)\end{array}$ & $\begin{array}{c}0.285^{* *} \\
(0.137)\end{array}$ & $\begin{array}{r}0.332 * * \\
(0.144)\end{array}$ & $\begin{array}{r}0.257 * * \\
(0.126)\end{array}$ & $\begin{array}{c}0.460 * * \\
(0.183)\end{array}$ & $\begin{array}{r}0.401 * * \\
(0.169)\end{array}$ & $\begin{array}{c}0.385^{* *} \\
(0.164)\end{array}$ \\
\hline $\begin{array}{l}\text { Omitted } \\
\text { observations/weights for } \\
\text { shocks }\end{array}$ & OPEC & $\begin{array}{c}\text { Oil } \\
\text { producers } \\
\text { with } 1 \% \text { of } \\
\text { world } \\
\text { production }\end{array}$ & $\begin{array}{c}\text { Oil } \\
\text { producers } \\
\text { with } 3 \% \text { of } \\
\text { world } \\
\text { production }\end{array}$ & $\begin{array}{l}\text { Top 1\% } \\
\text { high SE } \\
\text { countries }\end{array}$ & $\begin{array}{c}\text { Low oil } \\
\text { exporters }\end{array}$ & $\begin{array}{c}\text { Negative oil } \\
\text { price shocks } \\
\text { weighted by } \\
\text { oil } \\
\text { production } \\
\text { (\% GDP) }\end{array}$ & $\begin{array}{l}\text { Negative } \\
\text { oil price } \\
\text { shocks } \\
\text { weighted } \\
\text { by oil } \\
\text { rents (\% } \\
\text { GDP) } \\
\end{array}$ \\
\hline Number of observations & 763 & 708 & 753 & 786 & 387 & 529 & 559 \\
\hline Number of countries & 118 & 110 & 117 & 122 & 59 & 79 & 84 \\
\hline R-squared & 0.108 & 0.097 & 0.104 & 0.078 & 0.162 & 0.122 & 0.121 \\
\hline Country FE & Yes & Yes & Yes & Yes & Yes & Yes & Yes \\
\hline Year FE & Yes & Yes & Yes & Yes & Yes & Yes & Yes \\
\hline
\end{tabular}

In Table 5, we check whether our estimated effects differ between democracies and autocracies, by including an interaction dummy variable that takes the value of 1 if lagged Polity 2 score is strictly positive (negative) for democracies (autocracies). The dummy is included on its own and interacted with our variables of interest.

Table 5. Alternative Data Frequency

\begin{tabular}{|c|c|c|c|}
\hline Model & (1) & (2) & (3) \\
\hline & $\ln \operatorname{Tax}$ & $\ln T a x$ & $\ln \operatorname{Tax}$ \\
\hline & OLS & OLS & OLS \\
\hline \multirow[t]{2}{*}{ Negative price shock, $t$} & $7.211 * * *$ & $1.617 * *$ & $12.578^{*}$ \\
\hline & $(2.407)$ & $(0.707)$ & $(7.251)$ \\
\hline \multirow[t]{2}{*}{ Shadow economy, $t-1$} & 0.003 & 0.002 & 0.001 \\
\hline & $(0.007)$ & $(0.004)$ & $(0.005)$ \\
\hline Negative price shock, $t \times$ Shadow & $-0.128^{*}$ & $-0.041 * *$ & $-0.272 *$ \\
\hline economy, $t-1$ & $(0.076)$ & $(0.020)$ & $(0.160)$ \\
\hline \multirow[t]{3}{*}{ GDP per capita $(\log ), t$} & $0.339 * *$ & $0.330 * *$ & $0.391 * *$ \\
\hline & $(0.144)$ & $(0.146)$ & $(0.151)$ \\
\hline & $\begin{array}{c}\text { Including a dummy for } \\
\text { democracies + interactions }\end{array}$ & Annual observations & 5-year average \\
\hline Chow test (P value) & 0.14 & & \\
\hline Number of observations & 799 & 2,114 & 530 \\
\hline Number of countries & 124 & 124 & 124 \\
\hline R-squared & 0.106 & 0.077 & 0.172 \\
\hline Country FE & Yes & Yes & Yes \\
\hline Year FE & Yes & Yes & Yes \\
\hline \multicolumn{4}{|c|}{$\begin{array}{l}\text { The dependent variable is (log) tax revenue (\% of GDP. Negative oil price shock is the 3-year growth of log oil price multiplied by whole- } \\
\text { period average oil exports share to GDP. Column } 1 \text { uses the } 3 \text {-year average observations; column } 2 \text { uses annual observations; and column } \\
3 \text { uses 5-year average observations. In column } 1 \text {, the democracy dummy is included on its own and interacted with our variables of interest. } \\
\text { The method of estimation is ordinary least squares with Huber-robust standard errors (reported in parentheses) clustered at the country } \\
\text { level. Country fixed effects and year fixed effects are not reported. Significantly different from zero at } * 90 \% \text { confidence, } * * 95 \% \text { confidence, } \\
* * * 99 \% \text { confidence. }\end{array}$} \\
\hline
\end{tabular}


The results reported in column 1 show that our estimated coefficients preserved their signs and statistical significance. The included dummy and their interactions were statistically insignificant and reported chow test fail to reject the null hypothesis of equality of estimated effect in both democracies and autocracies. We proceed in columns 2 and 3 by showing that our results are not sensitive to the choice of data frequency. In column 2, we use annual observations and in column 3, we employ 5-year average observations. Our results remain again robust.

\section{Conclusion and Policy Implication}

We studied how the impact of falling in oil rents on tax revenues may be contingent on the size of shadow economy. Employing a simple theoretical model, we demonstrate that declining oil rents are less likely to increase the tax receipts of governments under a sizable shadow economy.

To test this prediction, we employ panel data covering the period 1991-2015 and more than 120 countries. Our theoretical prediction is supported by the data. In particular, the positive effects of falling oil rents on tax revenues decrease with higher levels of shadow economy. Our main results hold when we control for the effects of income, agriculture value added to GDP, trade, aid, , ethnicity, time-varying common shocks, country fixed effects, and quality of institutions (corruption, democracy, and political stability).

Our results contribute to the debate on the ambiguity of the role of the shadow economy in oil-dependent countries. On one hand, the existence of shadow economy can correct for market inefficiencies and allow workers to cope with economic volatility, but on the other hand, our findings suggest that it may impede government taxation efforts during economic downturns. In this regard, policy-makers are welladvised to analyze the shadow economy and its drivers as well as weigh the benefits and costs for its existence. Allowing for a limited role of the shadow economy can be conditionally beneficial if its size is kept under control. At the same time, government are recommended to embark labor market reforms in terms of increasing labor productivity, reducing obstacles for firm entry, offering flexible regulatory environment and employee social protection. This will allow for the reduction of the role of the shadow economy without losing its benefits.

We believe our results can also be relevant for oil-based economies under economic and energy sanctions (e.g., oil embargos for the case of Iran under Obama and Trump administrations). Do economic sanctions which are imposed on autocratic oil based economies constitute an effective tool to promote democracy in the sanctioned country? One possible channel through which oil sanctions (captured by negative oil rents shocks) may increase quality of political institutions is through expected positive response of taxation. If tax efforts of the state in response to negative oil shocks due to sanctions is positive and significant, then we may expect increased engagement of citizens in political decisionmaking (or at least higher willingness to political participation). Our findings show that the receivers of 
oil sanctions with a sizable shadow economy may suffer more from budget deficit due to their lower abilities to raise taxes.

\section{References}

Alexeev, M., and Conrad, R. (2009). The elusive curse of oil. The Review of Economics and Statistics, $91(3), 586-598$.

Aslaksen S. (2010). Oil and Democracy: More than a cross-country correlation?. Journal of Peace Research, 47(4), 421-431.

Bazzi, S., and Blattman, C. (2014). Economic shocks and conflict: evidence from commodity prices. American Economic Journal: Macroeconomics, 6, 1-38.

Beblawi, H., and Luciani, G. (1987). The Rentier State. Routledge, London: Taylor and Francis Group.

Besley, T., and Persson, T. (2014). Why do developing countries tax so little? Journal of Economic Perspectives, 28(4), 99-120.

Besley, T., and Persson, T. (2013). Taxation and development. In: A. Auerbach, R. Chetty, M. Feldstein and E. Saez, eds., Handbook of Public Economics, Amsterdam: Elsevier.

Besley, T., and Persson, T. (2011). Pillars of prosperity: The political economics of development clusters. Princeton, NJ: Princeton University Press.

Bjorvatn, K., and Farzanegan, M.R. (2015). Resource rents, balance of power, and political stability. Journal of Peace Research, 52, 758-773.

Bjorvatn, K., Farzanegan, M.R., and Schneider, F. (2012). Resource curse and power balance: evidence from oil rich countries. World Development, 40, 1308-1316.

Bornhorst, F., Gupta, S., and Thornton, J. (2009). Natural resource endowments and the domestic revenue effort. European Journal of Political Economy, 25(4), 439-446.

Boschini, A. D., Pettersson, J., and Roine, J. (2007). Resource curse or not: A question of appropriability. Scandinavian Journal of Economics, 109, 593-617.

BP (2018). Statistical Review of World Energy. BP p.l.c. Available at: https://www.bp.com/en/global/corporate/energy-economics/statistical-review-of-worldenergy.html

Brückner, M., and Ciccone, A. (2010). International commodity prices, growth and the outbreak of civil war in Sub-Saharan Africa. The Economic Journal, 120(544), 519-534.

Brückner, M., Ciccone, A., and Tesei, A. (2012). Oil price shocks, income, and democracy. Review of Economics and Statistics, 94(2), 389-399.

Bun, M. J., and Harrison, T. D. (2019). OLS and IV estimation of regression models including endogenous interaction terms. Econometric Reviews, 38(7), 814-827.

Crivelli, E., and Gupta, S. (2014). Resource blessing, revenue curse? Domestic revenue effort in resource-rich countries. European Journal of Political Economy, 35, 88-101.

Farzanegan, M.R. (2014). Can oil-rich countries encourage entrepreneurship? Entrepreneurship \& Regional Development, 26, 706-725.

Farzanegan, M. R. and Markwardt, G. (2009). The effects of oil price shocks on the Iranian economy. Energy Economics, 31 (1), 134-151.

Farzanegan, M.R. and Thum, M. (2018) Does oil rents dependency reduce the quality of education? Empirical Economics. DOI: https://doi.org/10.1007/s00181-018-1548-y

Fearon, J. (2003). Ethnic structure and cultural diversity by country . Journal of Economic Growth, 8(2), 195-222.

Frankel, J.F. (2010). The natural resource curse: A survey. NBER working paper, no. 15836. 
Gupta A.S (2007). Determinants of tax revenue efforts in developing countries. IMF Working Paper No. 07/184, Washington, DC.

Gupta, S., Clements, B., Pivovarsky, A., and Tiongson, E. R. (2004). Foreign aid and revenue response: does the composition of aid matter? in Helping Countries Develop: The Role of Fiscal Policy, ed. by Gupta, Clements, and Gabriela Inchauste, International Monetary Fund, Washington, DC.

Gylfason T (2001). Natural resources, education, and economic development. European Economic Review, 45, 847-859.

Hodler, R. (2006). The curse of natural resources in fractionalized countries. European Economic Review, 50, 1367-1386.

ICRG (2018). The International Country Risk Guide. The PRS Group.

Ishak, P. W., and Fritsche, U. (2019). Oil price shocks and protest: can shadow economy mitigate?. Macroeconomics and Finance Series 201901, University of Hamburg, Department of Socioeconomics.

Ishak, P. W. (2019). Autocratic survival strategies: Does oil make a difference? Peace Economics, Peace Science and Public Policy, 25(2), 1-22.

James, A. (2015). US State fiscal policy and natural resources. American Economic Journal: Economic Policy, 7(3), 238-257.

Jensen, A. (2011). State-building in resource-rich economies. Atlantic Economic Journal, 39(2), 171193.

Keen, M., and Simone, A. (2004). Tax policy in developing countries: some lessons from the 1990s and some challenges ahead. in helping countries develop: the role of fiscal policy, ed. by Sanjeev Gupta, Benedict Clements, and Gabriela Inchauste, International Monetary Fund, Washington, DC.

Mahdavy, H. (1970). The patterns and problems of economic development in rentier states: the case of Iran. In Cook M. A. (ed.), Studies in the Economic History of the Middle East, Oxford University Press.

Marshall, M.G., Gurr, T.R., and Jaggers, K., (2018). POLITY IV PROJECT. Center for Systemic Peace.

Medina, L., and Schneider, F. (2018). Shadow economies around the world: what did we learn over the last 20 years? IMF Working Paper No. 18/17, Washington, DC.

Mehlum, H., Moene, K., and Torvik, R. (2006). Institutions and the resource course. Economic Journal, $116,1-20$

Ross, M. (2012).The oil curse: how petroleum wealth shapes the development of nations. Princeton University Press, Princeton.

Ross, M. L. (2001). Does oil hinder democracy? World Politics, 53, 325-361.

Ross, M. and Mahdavi, P. (2015). Oil and Gas Data, 1932-2014. Harvard Dataverse. Available at: https://doi.org/10.7910/DVN/ZTPW0Y,

Sachs, J. D., and Warner, A.W., (1995). Natural resource abundance and economic growth. Harvard Institute for International Development, development discussion paper no. 517a.

Sachs, J. D., and Warner, A.W., (2001). The curse of natural resources. European Economic Review, $45,827-838$.

Schneider, F. (2005). Shadow economies around the world: what do we really know? European Journal of Political Economy, 21, 598-642.

Tsui, K. (2011). More oil, less democracy: evidence from worldwide crude oil discoveries. The Economic Journal, 121, 89-115.

UN Comtrade Database (2018). International Trade Statistics Database. United Nations, Available at: https://comtrade.un.org/ 
Van der Ploeg, R. (2011). Challenges and opportunities for resource rich economies. Journal of Economic Literature, 49(2), 366-420.

WDI (2018). World Development Indicators. The World Bank, Washington DC. 


\section{Appendix A}

\section{List of sampled countries}

Albania, Algeria, Angola, Argentina, Armenia, Australia, Austria, Azerbaijan, Bahamas, Bahrain, Bangladesh, Belarus, Belgium, Belize, Benin, Bolivia, Bosnia and Herzegovina, Botswana, Brazil, Bulgaria, Burundi, Canada, Chile, China, Colombia, Congo Rep., Costa Rica, Cote d'Ivoire, Croatia, Cyprus, Czech Republic, Denmark, Dominican Republic, Egypt, El Salvador, Estonia, Ethiopia, Fiji, Finland, France, Georgia, Germany, Ghana, Greece, Guatemala, Honduras, Hungary, Iceland, India, Indonesia, Iran, Ireland, Israel, Italy, Jamaica, Japan, Jordan, Kazakhstan, Kenya, Korea Rep., Kuwait, Kyrgyzstan, Laos, Latvia, Lebanon, Lesotho, Lithuania, Luxembourg, Madagascar, Malawi, Malaysia, Mali, Malta, Mauritius, Mexico, Moldova, Mongolia, Morocco, Mozambique, Myanmar, Namibia, Netherlands, New Zealand, Nicaragua, Nigeria, Norway, Oman, Pakistan, Papua New Guinea, Paraguay, Peru, Philippines, Poland, Portugal, Qatar, Romania, Russia, Rwanda, Senegal, Singapore, Slovakia, Slovenia, Solomon Islands, South Africa, Spain, Sri Lanka, Suriname, Sweden, Switzerland, Tanzania, Thailand, Togo, Trinidad and Tobago, Tunisia, Turkey, Uganda, Ukraine, United Arab Emirates, United Kingdom, United States, Uruguay, Vietnam, Zambia, Zimbabwe.

\section{List of countries with $\mathrm{SE}$ representing more than $35 \%$ of GDP}

Albania, Algeria, Angola, Armenia, Azerbaijan, Bahamas, Bangladesh, Belarus, Belize, Benin, Bolivia, Bosnia and Herzegovina, Botswana, Brazil, Bulgaria, Burundi, Colombia, Congo Rep., Cote d'Ivoire, Croatia, Cyprus, Dominican Republic, Egypt, El Salvador, Ethiopia, Georgia, Ghana, Guatemala, Honduras, Jamaica, Kazakhstan, Madagascar, Malawi, Malaysia, Mali, Mexico, Moldova, Morocco, Myanmar, Nicaragua, Nigeria, Pakistan, Papua New Guinea, Paraguay, Peru, Philippines, Romania, Russia, Rwanda, Senegal, Sri Lanka, Suriname, Tanzania, Thailand, Togo, Trinidad and Tobago, Tunisia, Turkey, Ukraine, Uruguay, Zambia, Zimbabwe.

\section{Control Variables}

- Agriculture value added (\% of GDP): Agriculture corresponds to ISIC divisions 1-5 and includes forestry, hunting, and fishing, as well as cultivation of crops and livestock production. Value added is the net output of a sector after adding up all outputs and subtracting intermediate inputs. It is calculated without making deductions for depreciation of fabricated assets or depletion and degradation of natural resources. Source: WDI (2018).

- Trade (\% of GDP): The sum of exports and imports of goods and services measured as a share of gross domestic product. Source: WDI (2018).

- Aid (\% of GNI): The share of official development assistance (ODA) to GNI. It consists of disbursements of loans made on concessional terms (net of repayments of principal) and grants by official agencies of the members of the Development Assistance Committee (DAC), by multilateral institutions, and by non-DAC countries in the DAC list of ODA recipients. Source: OECD (2018).

- Corruption: An index for corruption perceptions ranging from 1 to 6 , with higher values indicating less corruption. Source: ICRG (2018).

- Polity2: An index measuring the quality of political institutions. It ranges from 1 to 10 , with higher values indicating better institutional quality. Source: Marshall et al. (2018)

- Executive constraints: An index measuring imposed constraints on the powers of the executive. It ranges from 1 to 7, with higher values indicating more executive constraints. Source: Marshall et al. (2018)

- Political instability: measured by "Durable" variable counting the number of years since the most recent regime change that alters essential authority characteristics, as defined by a three-point change in Polity2 in a three-year period or less. Source: Marshall et al. (2018).

- Ethnicity: A measure for ethnic fractionalization taken from Fearon (2003). 


\section{Appendix B}

Marginal estimates for columns 6 (plot 1) and 7 (plot 2) in Table 4.
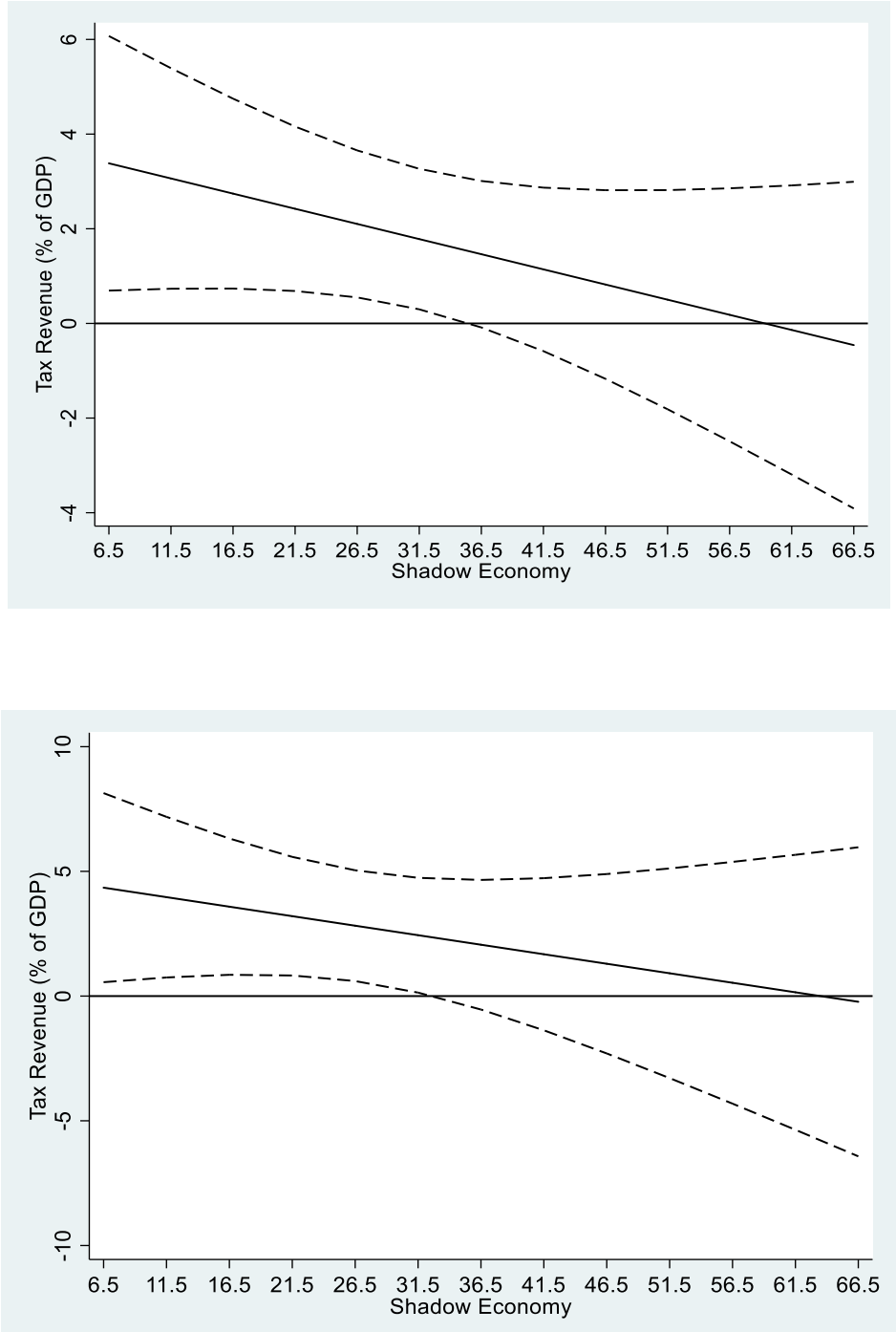